\section{Cancer-associated mutations in chromatin remodeler hSNF5 promote chromosomal instability by compromising the mitotic checkpoint}

\author{
Robert G.J. Vries, ${ }^{1,3,4}$ Vladimir Bezrookove, ${ }^{1,3}$ \\ Lobke M.P. Zuijderduijn, ${ }^{1,2}$ \\ Sima Kheradmand Kia, ${ }^{2}$ Ada Houweling, ${ }^{1}$ \\ Igor Oruetxebarria, ${ }^{1}$ Anton K. Raap, ${ }^{1}$ and \\ C. Peter Verrijzer ${ }^{1,2,5}$ \\ ${ }^{1}$ Department of Molecular and Cell Biology, Leiden \\ University Medical Centre, 2300 RA Leiden, \\ The Netherlands; ${ }^{2}$ Department of Biochemistry and Centre \\ for Biomedical Genetics, Erasmus University Medical Centre, \\ 3015 GE Rotterdam, The Netherlands
}

The hSNF5 subunit of human SWI/SNF ATP-dependent chromatin remodeling complexes is a tumor suppressor that is inactivated in malignant rhabdoid tumors (MRTs). Here, we report that loss of hSNF5 function in MRT-derived cells leads to polyploidization and chromosomal instability. Re-expression of hSNF5 restored the coupling between cell cycle progression and ploidy checkpoints. In contrast, cancer-associated hSNF5 mutants harboring specific single amino acid substitutions exacerbated poly- and aneuploidization, due to abrogated chromosome segregation. We found that hSNF5 activates the mitotic checkpoint through the $\mathrm{p}^{16^{\mathrm{INK}} 4 \mathrm{a}}-\mathrm{cy}$ clinD/CDK4-pRb-E2F pathway. These results establish that poly- and aneuploidy of tumor cells can result from mutations in a chromatin remodeler.

Received January 12, 2005; revised version accepted January 27, 2005.

ATP-dependent chromatin remodeling factors are critical components of the elaborate machinery that controls gene expression in eukaryotic cells (Becker and Horz 2002). The multisubunit SWI/SNF complex is the prototypical chromatin remodeling factor, present in all eukaryotes (Mohrmann and Verrijzer 2005). Human SNF5 (hSNF5, also known as Ini1, Baf47, or SmarcB1) encodes for a universal SWI/SNF subunit and tumor suppressor that is mutated in malignant rhabdoid tumors (MRTs) (Versteege et al. 1998; Klochendler-Yeivin et al. 2002; Roberts and Orkin 2004). MRTs are rare but highly aggressive pediatric cancers with a high mortality rate.

[Keywords: Chromosomal instability; chromatin; tumor suppressor; hSNF5/INI1/Baf47/SmarcB1]

${ }^{3}$ These authors contributed equally to this work.

${ }^{4}$ Present address: Department of Developmental Biology, Howard Hughes Medical Institute, Stanford University, Stanford, CA 94305, USA. ${ }^{5}$ Corresponding author.

E-MAIL c.verriizer@erasmusmc.nl; FAX 31-10-40879472.

Article and publication are at http://www.genesdev.org/cgi/doi/10.1101/ gad.335805.
Carriers of germline mutations are predisposed to various cancers and, consistent with a classic tumor suppressor phenotype, the wild-type allele is either lost or deleted in a large proportion of tumors (Biegel et al. 1999; Sevenet et al. 1999a,b; Taylor et al. 2000). hSNF5 mutations are also associated with a number of neoplasms other than MRTs (Grand et al. 1999; Sevenet et al. 1999a,b; Roberts and Orkin 2004). SNF5 inactivation studies in mice established its requirement during early embryogenesis and its role as a tumor suppressor (Klochendler-Yeivin et al. 2000; Roberts et al. 2000; Guidi et al. 2001; Roberts et al. 2002).

Several studies found that re-expression of hSNF5 in MRT-derived cell lines caused an accumulation in G0/ G1, cellular senescence, and apoptosis (Ae et al. 2002; Betz et al. 2002; Versteege et al. 2002; Zhang et al. 2002; Oruetxebarria et al. 2004). These effects are largely the result of direct transcriptional activation of the tumor suppressor p16 ${ }^{\mathrm{INK} 4 a}$ by hSNF5, which appears to be both necessary and sufficient for reduced cell proliferation and induction of cellular senescence and apoptosis (Oruetxebarria et al. 2004). p16 $6^{\mathrm{INK} 4 \mathrm{a}}$ controls the activity of $\mathrm{pRb}$ via inhibition of the cyclin D1-CDK4 kinase, which phosphorylates pRb (Lowe and Sherr 2003). Tumor suppressor $\mathrm{pRb}$ is a corepressor that is tethered to a broad range of genes by the E2F transcription factors. Hyperphosphorylation of $\mathrm{pRb}$ causes its dissociation from E2F, and relieves its antiproliferative activities. In addition to genes required for cell cycle progression from $\mathrm{G} 1$ to $\mathrm{S}$ phase, E2Fs also regulate genes involved in mitosis, spindle checkpoints, G2/M control, apoptosis, and differentiation (Stevaux and Dyson 2002).

Besides uncontrolled cell proliferation, chromosomal instability, which is characterized by changes in chromosome number or structure, is a hallmark of cancer cells (Rajagopalan and Lengauer 2004). Although still debated, there has been increasing support for the idea that polyploidy can lead to aneuploidy and contribute to the development of cancer (Rajagopalan and Lengauer 2004; Storchova and Pellman 2004). Although gross aneuploidy appears to be rare, chromosomal imbalances are commonly detected in MRTs and other hSNF5-related cancers (Berrak et al. 2002; Mitelman et al. 2003; Rickert and Paulus 2003; Kusafuka et al. 2004). Therefore, we decided to investigate the role of hSNF5 in ploidy control. Our results define a critical function for this chromatin remodeler in the maintenance of numerical chromosome stability.

\section{Results and Discussion}

hSNF5 deficiency in MRT cells leads to polyploidization

In the majority of MRTs, hSNF5 is inactivated due to deletions, truncating nonsense mutations, or frameshift mutations. However, a number of point mutations, resulting in single amino acid substitutions (Fig. 1A), have been identified in tumors (Sevenet et al. 1999a,b). These include proline 48 to serine (P48S), arginine 127 to glycine (R127G), and serine 284 to leucine (S284L). In addition, we also changed serine 289 to alanine (S289A). S284 and S289 are located within one of the most highly con- 
A
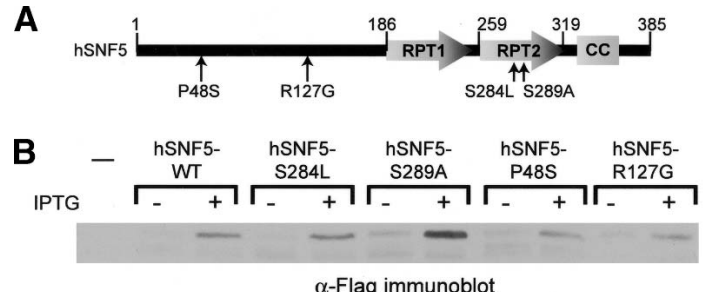

$\alpha-$ Flag immunoblot

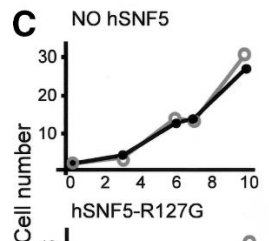

hSNF5-WT

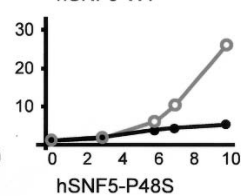

hSNF5-S284L

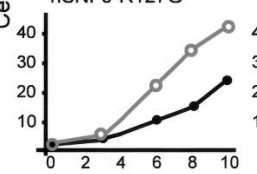

Days of induction, (०) - IPTG hSNF5 off, (•) + IPTG hSNF5 on

Figure 1. Effect of wild-type or mutant hSNF5 expression in MRT cells. (A) Schematic representation of hSNF5 depicting the two repeats (RPT1 and RPT2) and cancer-associated amino acid substitution mutations. $(B)$ Constructs expressing wild-type or mutant hSNF5-Flag were introduced in the MRT-derived cell line G401 under control of the Lac repressor-operator system. Protein expression following induction with IPTG was determined by Western blotting with anti-Flag antibodies. $(C)$ Cell accumulation in the presence (filled circles) or absence (open circles) of hSNF5, induced by IPTG.

served regions of SNF5, which forms part of direct repeat 2 (RPT2).

Wild-type or mutant hSNF5 was reintroduced in MRT-derived G401 cells lacking the hSNF5 gene. Expression of hSNF5 was under control of the Lac repressor-operator system and could be induced by the addition of IPTG (Fig. 1B). Previously, we used these "LachSNF5" cells to establish that re-expression of hSNF5 in MRT cells induces a p16 $6^{\mathrm{INK} 4 \mathrm{a}}$-dependent G0/G1 arrest, cellular senescence, and apoptosis (Oruetxebarria et al. 2004). It should be noted that the induced levels of hSNF5 fall within the normal physiological range (Oruetxebarria et al. 2004) and that hSNF5 is not required for the assembly of a SWI/SNF complex (Doan et al. 2004; Oruetxebarria et al. 2004). Induction of tumorderived hSNF5 mutants still caused a reduced cell accumulation, albeit not as pronounced as when wild-type hSNF5 was expressed (Fig. 1C). As expected, addition of IPTG to "Lac-empty" control cells, lacking the hSNF5 gene, did not affect cell accumulation. These results indicated that a failed growth arrest might not fully explain the cancer association of these single amino acid substitutions in hSNF5.

Examination of the nuclear morphology of cells expressing mutant hSNF5-S284L provided a clue towards other processes relevant to tumor suppression by hSNF5 (Fig. 2A,B). Four days after induction of hSNF5-S284L, the majority of cells contained multilobed nuclei or sometimes multiple nuclei. We never observed multilobed nuclei after expression of wild-type hSNF5, whereas they occurred regularly in cells lacking hSNF5. Next, we tested the effect of hSNF5-S284L on unrelated cells, expressing endogenous wild-type hSNF5. In both MRC-5V1 (Fig. 2C) and Ad5HER cells (data not shown), expression of hSNF5-S284L induced multilobed nuclei, whereas overexpression of wild-type hSNF5 had no effect. Thus, the S284L substitution mutation can have a dominant effect, which is not restricted to MRT cells.

Because multilobed nuclei are a feature of cells that have undergone endoreplication, we tested whether hSNF5-S284L might promote polyploidization. The full karyotypes of G401 MRT-derived cells that either lack hSNF5 or express wild-type hSNF5 or hSNF5-S284L were determined by multicolor pq-COBRA-FISH analysis (Fig. 2D; Wiegant et al. 2000). About $90 \%$ of Lacempty cells or Lac-hSNF5 cells before induction were in the diploid range of chromosome content, but displayed frequent numerical chromosome aberrations. The remaining $10 \%$ was near tetraploid. Strikingly, after expression of wild-type hSNF5 for $96 \mathrm{~h}$, the cell population became almost perfectly diploid. The disappearance of aneuploid cells from the cycling population suggested a role for hSNF5 in mitotic checkpoint control. In contrast, hSNF5-S284L expression exacerbated poly- and aneuploidization, resulting in $\sim 25 \%$ of cells in the tetraploid range and almost $10 \%$ of cells that were near octaploid. We note that, because mitotic cells were obtained by a colcemid block, the karyotypes were derived from cycling cells. Moreover, the presence of octaploid cells demonstrated that a significant portion of tetraploid cells did not arrest due to the tetraploidy checkpoint but re-entered mitosis.

Concomitant with polyploidization we observed centrosome- and spindle amplification, as revealed by $\gamma$-tubulin and $\alpha$-tubulin staining, respectively (Fig. 2E,F). Following hSNF5-S284L induction, the percentage of mitotic cells containing more than one spindle increased from $\sim 5 \%$ to, respectively, $22 \%$ of cells with two spindles and $11 \%$ with more than two spindles. However, mitotic cells expressing wild-type hSNF5 virtually always contain one spindle. In summary, these results revealed that loss of hSNF5 in MRT cells promotes polyand aneuploidization, whereas the cancer-associated S284L substitution acts as a gain-of-function mutation, exacerbating chromosomal instability. Collectively, these observations suggest a critical function for hSNF5 during mitosis.

\section{Mutations in hSNF5 abrogate chromosome segregation}

We utilized time-lapse microscopy to determine the cell cycle stage at which the hSNF5-S284L-induced defect occurs (Fig. 3A). Cells expressing hSNF5-S284L enter mitosis normally, as judged by rounding up of the cells and chromosomal condensation (indicated with an arrow). However, a significant proportion of these cells subsequently exited mitosis, as judged by cell flattening and chromatin decondensation, but abstained from karyokinesis and cytokinesis. Most cells that do not express hSNF5-S284L progress normally through mitosis and cell division. Quantification of distinct stages of mitosis revealed a defective anaphase in hSNF5-S284L-expressing cells (data not shown). The aborted anaphase appeared to be caused by a failure of the mitotic spindle to connect to the kinetochores, as revealed by confocal microscopy using CREST and $\alpha$-tubulin antibodies to visualize kinetochores and spindles, respectively (Fig. 3B). In cells expressing wild-type hSNF5, however, the spindles 


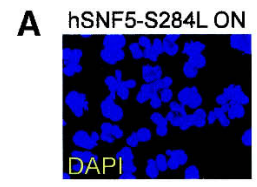

hSNF5-S284L OFF

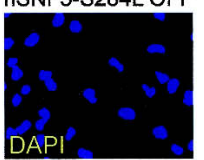

\section{B}

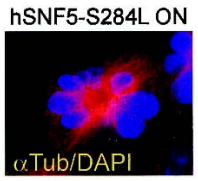

hSNF5-S284L OFF

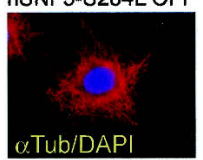

C

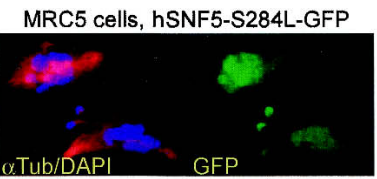

MRC5 cells, WT hSNF-GFP

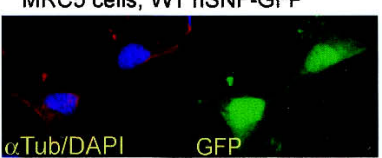

E

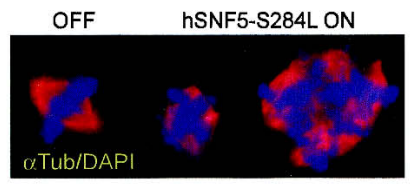

$\mathbf{F}$

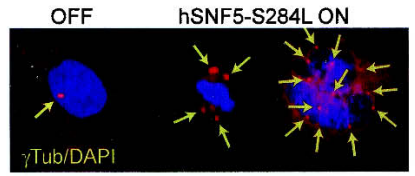

D
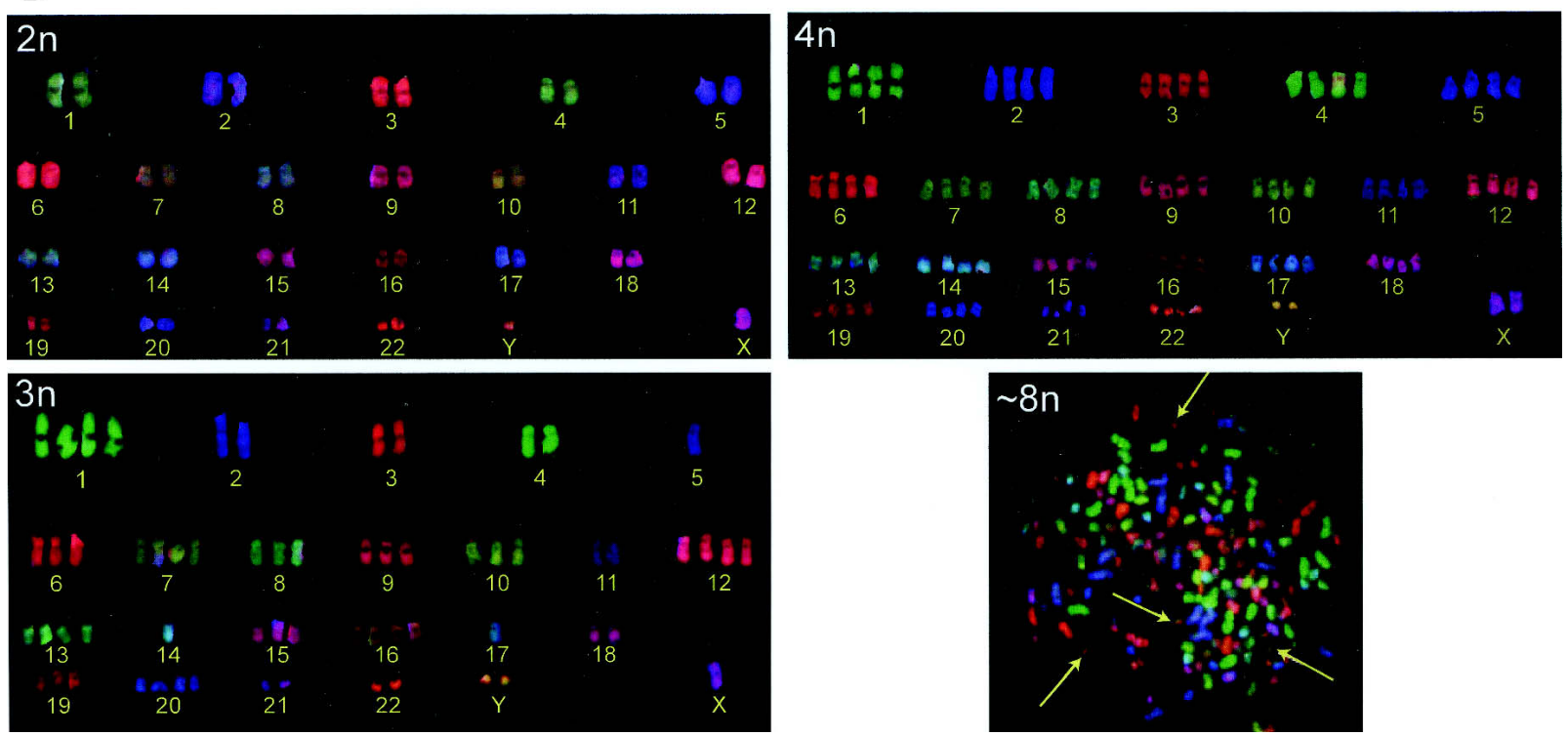

Figure 2. hSNF5-S284L expression exacerbates polyploidization. (A) DNA staining with DAPI revealed an increased number of multilobed nuclei after hSNF5-S284L expression. (B) Costaining of DNA (blue) and $\alpha$-tubulin (red). (C) GFP-hSNF5-S284L but not GFP-hSNF5 induces multilobed nuclei in MRC5 cells. The GFP signal (green) identifies the transfected cells. $(D)$ Representative examples of pq-COBRA-FISH analysis of Lac-hSNF5-S284L cells. Di-, tri, tetra-, and near octaploid metaphases are shown. Four Y-chromosomes, indicative of octaploidy, are indicated by arrows. (E) Representative examples of Lac-hSNF5-S284L cells with one, two, or more mitotic spindles. $(F)$ Visualization of centrosomes (arrows) by $\gamma$-tubulin staining.

provided an orderly connection between metaphase chromosomes and centrosomes. Expression of hSNF5S289A had similar effects on mitosis as hSNF5-S284L. It will be of interest to investigate whether S284 and S289 might be targets for phosphorylation, regulating the mitotic functions of hSNF5.

\section{hSNF5 is critical for precise ploidy control}

We used pq-COBRA-FISH to determine the effects of cancer-associated mutations in hSNF5 on ploidy distribution (Fig. 4A) and on numerical chromosome variation, as determined by the gain or loss of individual chromosomes (Fig. 4B). Examination of cells prior to induction of hSNF5 revealed that more than half displayed general numerical chromosomal aberrations and that $\sim 10 \%$ were near tetraploid. Strikingly, after hSNF5 induction virtually all poly- and aneuploid cells were purged and the cell population became almost perfectly diploid. This dramatic effect of hSNF5 expression on numerical chromosome instability was highly significant $\left(p<2.0 \times 10^{-6}\right)$, as determined by the Mann-Whitney Utest. Thus, restoration of hSNF5 expression in MRT-derived cells, which lost the hSNF5 gene in the original cancerous lesion, suffices to revert chromosomal instability. In contrast, two different cancer-associated hSNF5 substitution mutants, hSNF5-P48S and hSNF5-

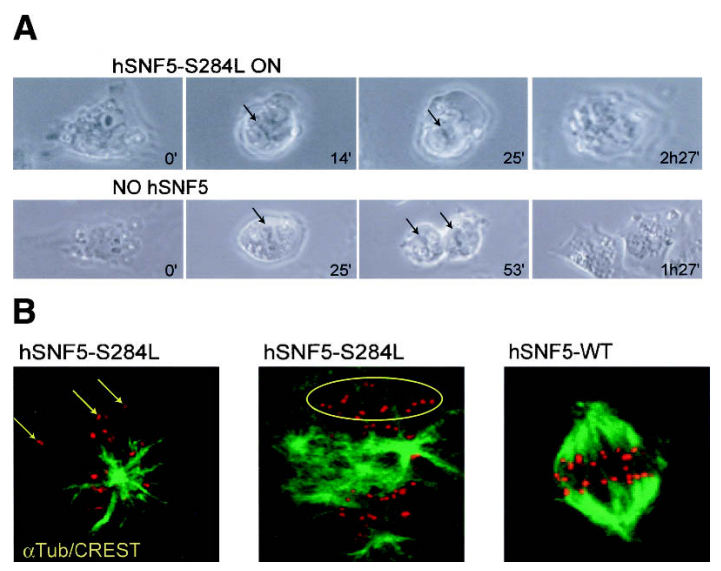

Figure 3. hSNF5-S284L induction causes an abortive cell cycle. (A) Time-lapse microscopy of hSNF5-S284L-expressing cells, which en ter mitosis but exit prior to cell division. Arrows indicate condensed chromatin. (B) Failure of microtubule-kinetochore association in cells expressing hSNF5-S284L. Kinetochores were identified with CREST (red) antibodies and mitotic spindles with $\alpha$-tubulin (green) antibodies. 
Vries et al.
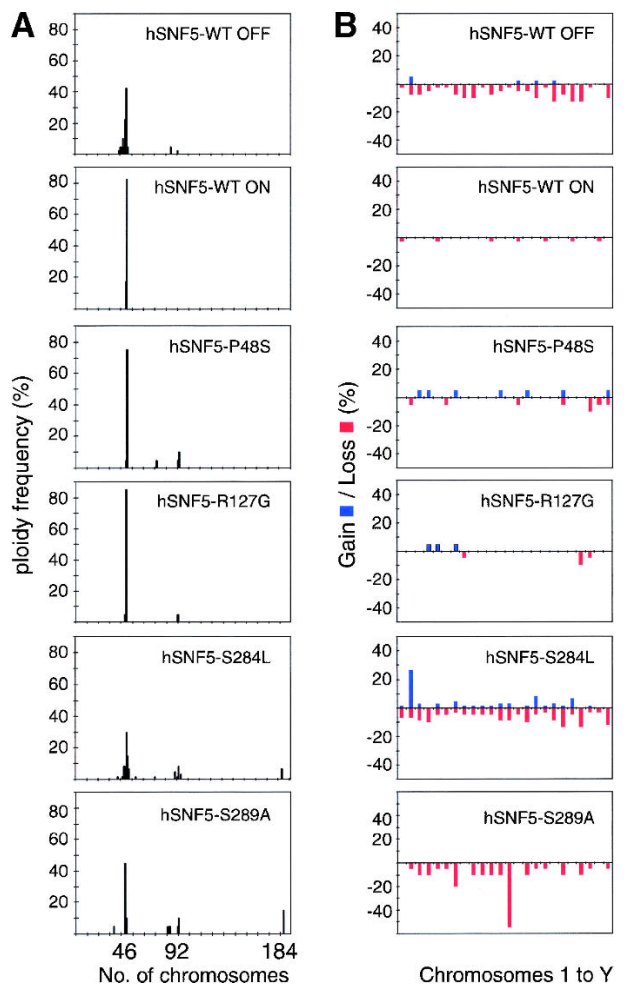

Figure 4. Restoration of wild-type hSNF5 expression, but not of cancer-associated mutants, reverts chromosomal instability. $(A)$ Histogram depicting the frequency of cells with a given chromosome number as determined by metaphase analysis using pq-COBRA-FISH. The total number of chromosomes per cell was determined either before or after the induction of hSNF5. $(B)$ Individual chromosome gains or losses.

R127G, failed to generate a diploid cell population. Expression of either hSNF5-S284L $\left(p<3.6 \times 10^{-5}\right)$ or hSNF5-S289A $\left(p<2 \times 10^{-6}\right)$ strongly promoted polyploidization and aneuploidy. In conclusion, our analysis of both loss-of-function and gain-of-function mutations revealed the critical role of hSNF5 in ploidy control.

hSNF5 activates the mitotic checkpoint through the p16 ${ }^{I N K 4 a}$-cyclinD/CDK4-pRb-E2F pathway

Our results suggested that re-expression of hSNF5 tightens the mitotic checkpoint such that cell cycle progression of cells with an abnormal ploidy is blocked. To karyotype these noncycling cells, we used the drug calyculin A to induce premature chromosome condensation of interphase cells (Bezrookove et al. 2003). Indeed, we found that the karyotypes of noncycling hSNF5-expressing cells displayed a significantly higher degree of chromosome gains and losses than those of mitotic cells $\left(p<10^{-2}\right)$ (Fig. 5A,B). These results suggest that the reduced accumulation of hSNF5-expressing cells is caused by selective arrest and senescence of aneuploid cells. After hSNF5 induction, only diploid cells remain cycling.

Next, we considered the pathway through which hSNF5 controls cellular ploidy. Whole-genome expression profiling of Lac-hSNF5 cells prior to and after hSNF5 induction revealed, among other findings, changed expression of many E2F targets, including mitotic control genes. This is illustrated by the representa- tive selection in Figure 5C. Interestingly, recent studies established that the $\mathrm{pRb}-\mathrm{E} 2 \mathrm{~F}$ pathway couples cell cycle progression to the mitotic checkpoint (Hernando et al. 2004). Our earlier work had already shown that the ability of $\mathrm{p} 16^{\mathrm{INK} 4 \mathrm{a}}$ to inhibit CDK4 kinase activity was critical for hSNF5-induced senescence (Oruetxebarria et al. 2004). To test whether ploidy control by hSNF5 is exerted via the $\mathrm{p} 16^{\mathrm{INK} 4 \mathrm{a}}-$ cyclinD/CDK4-pRb-E2F pathway, we debilitated this route by expression of the p16 ${ }^{\text {INK4a }}$-insensitive CDK4 ${ }^{\text {R24C }}$ mutant (Rane et al. 2002). Karyotypic analysis revealed that the high level of poly- and aneuploidy of these cells could not be reversed by hSNF5 expression (Fig. 5D-F). Thus, derailment of the $\mathrm{pRb}$ pathway blocks ploidy control by hSNF5.

Our gene expression profiling results suggested that misexpression of mitotic checkpoint components might cause the abnormal ploidy of MRT cells. For example, overexpression of Mad2 and its regulator E2F1 was recently implicated in mitotic defects leading to aneuploidy (Hernando et al. 2004). Interestingly, in our microarray experiments, both genes were down-regulated following hSNF5 induction. We used RT-PCR to corroborate our microarray results (Fig. 5G). We found that both Mad2 and E2F1 are highly expressed in MRT cells, but are strongly down-regulated following hSNF5 induction. CDK4 ${ }^{\mathrm{R} 24 \mathrm{C}}$ expression abrogated attenuation of these genes by hSNF5. Collectively, these results suggest that in MRT cells, loss of hSNF5 function causes elevated levels of Mad2 due to unregulated E2F1 activity. This in turn can be sufficient to cause a defective spindle checkpoint driving aneuploidization, as shown by Hernando et al. (2004).

We conclude that transcriptional regulation of the p16 ${ }^{\text {INK4a }}$-cyclinD/CDK4-pRb-E2F pathway plays a critical role in ploidy control by hSNF5. However, this does not exclude additional functions for hSNF5 in ploidy control or other cellular processes relevant for tumorigenesis. Moreover, a more structural role in the establishment of centromeric chromatin or in sister chromatid cohesion and segregation remains possible, as has been suggested for the SWI/SNF-related yeast RSC complex (Baetz et al. 2004; Huang et al. 2004; Mohrmann and Verrijzer 2005). Using a conditional siRNA approach, we recently observed polyploidization of non-MRT cells due to the loss of hSNF5 (R.G.J. Vries and C.P. Verrijzer, unpubl.), suggesting that the mitotic functions of hSNF5 might be general and not cell-type-specific.

Inactivation of ATP-dependent chromatin remodeling factors has been implicated in the development of distinct types of tumors (Klochendler-Yeivin et al. 2002; Roberts and Orkin 2004). Here, we report that restoration of hSNF5 expression in MRT-derived cells, which lost the hSNF5 gene in the original cancerous lesion, leads to the purging of poly- and aneuploid cells. We propose that inactivation of chromatin remodeler hSNF5 causes both the selective growth advantage and the genetic instability necessary for tumor initiation and progression. Our finding that hSNF5 activates the mitotic checkpoint through the p16 ${ }^{\mathrm{INK} 4 \mathrm{a}}-\mathrm{cyclinD} / \mathrm{CDK} 4-\mathrm{pRb}-\mathrm{E} 2 \mathrm{~F}$ pathway reveals a convergence of tumor suppressor pathways.

\section{Materials and methods}

Cell culture, plasmids, and mRNA expression

Generation and culture of the G401 cell lines has been described (Oruetxebarria et al. 2004). CDK4 $4^{\mathrm{R} 24 \mathrm{C}}$ was stably expressed in Lac- 
A

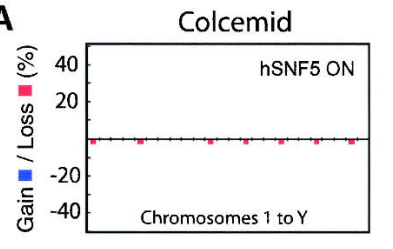

C

\# symbol, name

$1 \mathrm{ORC} 1 \mathrm{~L}$, origin recognition complex 1

2 ORC4L, origin recognition complex 4

3 PRIM2A, primase polypeptide $2 a$

4 PRIM1, primase polypeptide 1

5 RFC3, replication factor $\mathrm{C}_{3}$

6 POLA, DNA directed polymerase alpha

7 DUT, dUTP pyrophophatase

8 ATM, ataxia telangiectasia mutated

9 FEN1, flap structure-specific endonuclease 1

10 MCMs2-7,10, minichromosome maintenance deficient

11 PPP2R1B, protein phosphatase 2, PP2A

12 CHES1, checkpoint suppressor 1

13 CDKN2A, cyclin-dependent kinas

14 E2F1, E2F transcription factor 1

$15 \mathrm{CDC2}$, cell division cycle 2

16 CCNB1, cyclin B1

$17 \mathrm{CDC} 25 \mathrm{C}$, cell division cycle 25C

18 CDC25A, cell division cycle 25A

19 CCNF, cyclin F

20 CENPE, centromere protein $\mathrm{E}$

21 PLK2, polo-like kinase 2

22 MAD2L, mitotic arrest deficien

23 TERF1, telomeric repeat binding factor 1

$24 \mathrm{CHC1}$, chromosome condensation 1

25 PTEN, phosphatase and tensin homolog

26 ESPL1, extra spindle poles-like 1

27 KNTC1, kinetochore associated 1
B Calyculin A

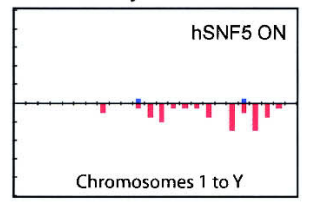

D CDK4(R24C) \pm hSNF5

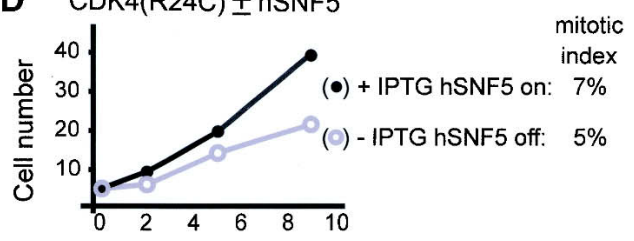

Days of induction

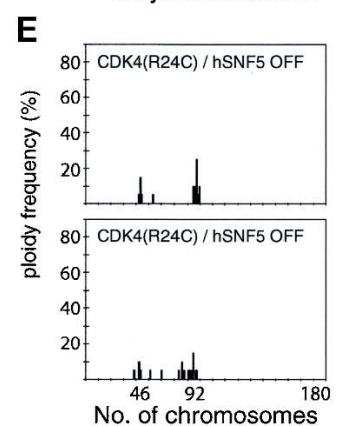

Genbank \# target change

$\begin{array}{lll}\text { U40152 } & \text { E2F } & -1.7 \\ \text { AF022108 } & \text { E2F } & -1.6\end{array}$

Bc064931 E2F -1.9

AA761682 E2F -1.6

AL596753 EPF -1.5

$\begin{array}{lll}X 06745 & \mathrm{E} 2 \mathrm{~F} & -1.6\end{array}$

U62891.1 E2F $\quad-1.9$

U33841 E2F 1.17

$\mathrm{BC} 000323 \quad \mathrm{E} 2 \mathrm{~F} \quad-1.5$

multiple genes E2F

AW009884 $\quad 4.6$

AA149521 E2F +1.6

U38945 +2.0

$\begin{array}{lll}M 96577 & E 2 F & -3.2\end{array}$

D88357 E2F $\quad-1.6$

BE407516 E2F -1.6

A1917350 E2F -1.6

A1917350 E2F -2.3

Z36714 E2F -2.3

$\begin{array}{lll}Z 15005 & \text { E2F } & -2.0\end{array}$

AF059617 E2F +2.4

NM_002358.2 E2F $\quad-1.7$

AF003001

NM_001269.1

U96180.1

D79987

AA157787
$F$

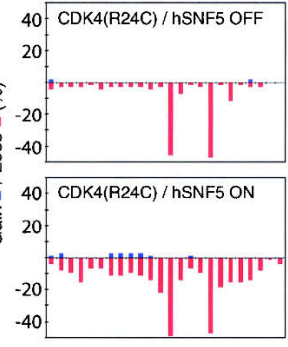

Chromosomes 1 to $Y$
G

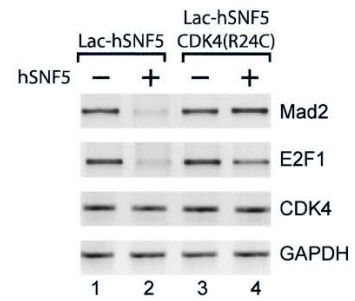

Figure 5. Expression of $\mathrm{p} 16^{\mathrm{INK} 4 \mathrm{a}}$-insensitive $\mathrm{CDK} 4^{\mathrm{R} 24 \mathrm{C}}$ blocks hSNF5-induced mitotic checkpoint activation. Individual chromosome gains or losses as determined by karyotyping after a colcemid block $(A)$ or calyculin A-induced premature chromosome condensation $(B)$ of interphase cells. $(C)$ Selection of E2F targets and mitotic controllers, regulated by hSNF5 identified by whole-genome expression profiling. Gene symbols according to unigene convention, known E2F targets, and fold changes in expression following hSNF5 are indicated. $(D)$ Cell accumulation of Lac-hSNF5 cells stably expressing CDK4 ${ }^{\mathrm{R} 24 \mathrm{C}}$ in the presence (filled circles) or absence (open circles) of hSNF5. (E) Histogram depicting the frequency of cells with a given chromosome number. $(F)$ Individual chromosome gains or losses. $(G)$ RT-PCR analysis of gene expression. The same mRNA isolates were used to detect expression of the indicated genes.

hSNF5 cells (Lac-hSNF5/CDK4 ${ }^{\text {R24C) }}$ from a pREP4-derived vector (Rane et al. 2002). Mutants were generated using QuickChange mutagenesis (Stratagene). mRNA expression analysis was performed as described (Oruetxebarria et al. 2004). All primer sequences will be provided upon request. Gene expression profiling was performed using Affymetrix U133A GeneChips, and data analyses were performed using Omniviz software and the Ease program. An extensive description of these experiments will be reported elsewhere.

Immunofluorescence and time-lapse microscopy

Cells were grown on cover slips, fixed with $4 \%$ paraformaldehyde, and permeabilized in PBS with $0.1 \%$ Triton X-100, followed by standard indirect immunofluorescence. Nuclei were visualized by DAPI staining. Antibodies used: anti-Flag, F3165 (Sigma); anti- $\alpha$-tubulin, T5168 (Sigma); anti- $\gamma$-tubulin, T6557 (Sigma); anti-CREST was a gift from H. Clevers (Hubrecht Laboratory, Utrecht, The Netherlands) (Fodde et al. 2001). To quantify centrosome- and spindle amplification, $\sim 1000$ mitotic cells for each condition were analyzed. Cells for time-lapse microscopy were grown on glass-bottom culture dishes (MatTek). Two hours before transfer to the $37^{\circ} \mathrm{C}$ microscope, medium was changed to HEPES-buffered DMEM without Phenol red (21063-029, Life Technology).

pq-COBRA-FISH and cytogenetic analysis

Detailed cytogenetic analysis using pq-COBRA-FISH was performed essentially as described (Wiegant et al. 2000). ULS reagent was provided by Kreatech Biotechnology. Interphase cells were karyotyped following Calyculin A-induced chromosome condensation (Bezrookoove et al. 2003). For each condition, between 20 and 60 cells were analyzed. Chromosome copy number is depicted as histograms, and the numerical abnormalities are presented as percentage of gain and loss for each chromosome, for which the nearest ploidy of each cell was considered. The significance of differences in total gain or loss of chromosomes was determined by the Mann-Whitney U-test.

\section{Acknowledgments}

We thank N. Nagelkerke for help with the statistical analysis; S. Swagemarkers, C. Gaspar, and R. Fodde for help with the microarray analysis; H. Clevers for anti-CREST serum; M.J. van der Burg for help with COBRA-FISH analysis; R. Dirks for advice on microscopy; R. Fodde for discussions; and J. Svejstrup, R. Fodde, M. Gorski, and T. Mahmoudi for comments on the manuscript. This work was supported by a grant from the Dutch Cancer Society (KWF) to C.P.V.

\section{References}

Ae, K., Kobayashi, N., Sakuma, R., Ogata, T., Kuroda, H., Kawaguchi, N., Shinomiya, K., and Kitamura, Y. 2002. Chromatin remodeling factor encoded by inil induces G1 arrest and apoptosis in inil-deficient cells. Oncogene 21: 3112-3120.

Baetz, K.K., Krogan, N.J., Emili, A., Greenblatt, J., and Hieter, P. 2004. The ctf13-30/CTF13 genomic haploinsufficiency modifier screen identifies the yeast chromatin remodeling complex RSC, which is required for the establishment of sister chromatid cohesion. Mol. Cell Biol. 24: 1232-1244.

Becker, P.B. and Horz, W. 2002. ATP-dependent nucleosome remodeling. Annu. Rev. Biochem. 71: 247-273.

Berrak, S.G., Ozek, M.M., Canpolat, C., Dagcunar, A., Sav, A., El-Naggar, A., and Langford, L.A. 2002. Association between DNA content and tumor suppressor gene expression and agressiveness of atypical tera- 
Vries et al.

toid/rhabdoid tumors. Child's Nerv. Syst. 18: 485-491.

Betz, B.L., Strobeck, M.W., Reisman, D.N., Knudsen, E.S., and Weissman, B.E. 2002. Re-expression of hSNF5/INI1/BAF47 in pediatric tumor cells leads to G1 arrest associated with induction of p16ink4a and activation of RB. Oncogene 21: 5193-5203.

Bezrookove, V., Smits, R., Moeslein, G., Fodde, R., Tanke, H.J., Raap, A.K., and Darroudi, F. 2003. Premature chromosome condensation revisited: A novel chemical approach permits efficient cytogenetic analysis of cancers. Genes Chrom. Cancer 38: 177-186.

Biegel, J.A., Zhou, J.Y., Rorke, L.B., Stenstrom, C., Wainwright, L.M., and Fogelgren, B. 1999. Germ-line and acquired mutations of INI1 in atypical teratoid and rhabdoid tumors. Cancer Res. 59: 74-79.

Doan, D.D., Veal, T.M., Yan, Z., Wang, W., Jones, S.N., and Imbalzano, A.N. 2004. Loss of the INI1 tumor suppressor does not impair the expression of multiple BRG1-dependnet genes or the assembly of SWI/SNF enzymes. Oncogene 23: 3462-3473.

Fodde, R., Kuipers, J., Rosenberg, C., Smits, R., Kielman, M., Gaspar, C., van Es, J.H., Breukel, C., Wiegant, J., Giles, R.H., et al. 2001. Mutations in the APC tumour suppressor gene cause chromosomal instability. Nat. Cell Biol. 3: 433-438.

Grand, F., Kulkarni, S., Chase, A., Goldman, J.M., Gordon, M., and Cross, N.C. 1999. Frequent deletion of hSNF5/INI1, a component of the SWI/SNF complex, in chronic myeloid leukemia. Cancer Res. 59: 3870-3874.

Guidi, C.J., Sands, A.T., Zambrowicz, B.P., Turner, T.K., Demers, D.A., Webster, W., Smith, T.W., Imbalzano, A.N., and Jones, S.N. 2001. Disruption of Inil leads to peri-implantation lethality and tumorigenesis in mice. Mol. Cell Biol. 21: 3598-3603.

Hernando, E., Nahle, Z., Juan, G., Diaz-Rodriguez, E., Alaminos, M., Hemann, M., Michel, L., Mittal, V., Gerald, W., Benezra, R., et al. 2004. $\mathrm{Rb}$ inactivation promotes genomic instability by uncoupling cell cycle progression from mitotic control. Nature 430: 797-802.

Huang, J., Hsu, J.M., and Laurent, B.C. 2004. The RSC nucleosome-remodeling complex is required for Cohesin's association with chromosome arms. Mol. Cell 13: 739-750.

Klochendler-Yeivin, A., Fiette, L., Barra, J., Muchardt, C., Babinet, C., and Yaniv, M. 2000. The murine SNF5/INI1 chromatin remodeling factor is essential for embryonic development and tumor suppression. EMBO Rep. 1: 500-506.

Klochendler-Yeivin, A., Muchardt, C., and Yaniv, M. 2002. SWI/SNF chromatin remodeling and cancer. Curr. Opin. Genet. Dev. 12: $73-$ 79.

Kusafuka, T., Miao, J., Yoneda, A., Kuroda, S., and Fukuzawa, M. 2004. Novel germ-line deletion of SNF5/INI1/SMARCB1 gene in neonate presenting with congenital malignant rhabdoid tumor of kidney and brain primitive neuroectodermal tumor. Genes Chromosomes Cancer 40: 133-139.

Lowe, S.W. and Sherr, C.J. 2003. Tumor suppression by Ink4a-Arf: Progress and puzzles.Curr. Opin. Genet. Dev. 13: 77-83.

Mitelman, F., Johansson, B., and Mertens, F. 2003. Mitelman database of chromosome aberrations in cancer. http://cgap.nci.nih.gov/Chromosomes/Mitelman

Mohrmann, L. and Verrijzer, C.P. 2005. Composition and functional specificity of SWI2/SNF2 class chromatin remodeling complexes. Biochim. Biophys. Acta 1681: 59-73.

Oruetxebarria, I., Venturini, F., Kekarainen, T., Houweling, A., Zuijderduijn, L.M., Mohd-Sarip, A., Vries, R.G., Hoeben, R.C., and Verrijzer, C.P. 2004. P16INK4a is required for hSNF5 chromatin remodelerinduced cellular senescence in malignant rhabdoid tumor cells. $J$. Biol. Chem. 279: 3807-3816.

Rajagopalan, H., and Lengauer, C. 2004. Aneuploidy and cancer. Nature 432: $338-341$.

Rane, S.G., Cosenza, S.C., Mettus, R.V., and Reddy, E.P. 2002. Germ line transmission of the Cdk4(R24C) mutation facilitates tumorigenesis and escape from cellular senescence. Mol. Cell Biol. 22: 644-656.

Rickert, C.H., and Paulus, W. 2004. Chromosomal imbalances detected by comparative genomic hybridisation in atypical teratoid/rhabdoid tumours. Childs Nerv. Syst. 20: 221-224.

Roberts, C.W. and Orkin, S.H. 2004. The SWI/SNF complex-Chromatin and cancer. Nat. Rev. Cancer 4: 133-142.

Roberts, C.W., Galusha, S.A., McMenamin, M.E., Fletcher, C.D., and Orkin, S.H. 2000. Haploinsufficiency of Snf5 (integrase interactor 1) predisposes to malignant rhabdoid tumors in mice. Proc. Natl. Acad.
Sci. 97: 13796-13800.

Roberts, C.W., Leroux, M.M., Fleming, M.D., and Orkin, S.H. 2002. Highly penetrant, rapid tumorigenesis through conditional inversion of the tumor suppressor gene Snf5. Cancer Cell 2: 415-425.

Sevenet, N., Lellouch-Tubiana, A., Schofield, D., Hoang-Xuan, K., Gessler, M., Birnbaum, D., Jeanpierre, C., Jouvet, A., and Delattre, O. 1999a. Spectrum of hSNF5/INI1 somatic mutations in human cancer and genotype-phenotype correlations. Hum. Mol. Genet. 8: 23592368.

Sevenet, N., Sheridan, E., Amram, D., Schneider, P., Handgretinger, R., and Delattre, O. 1999b. Constitutional mutations of the hSNF5/INI1 gene predispose to a variety of cancers. Am. J. Hum. Genet. 65: 13421348.

Stevaux, O. and Dyson, N.J. 2002. A revised picture of the E2F transcriptional network and RB function. Curr. Op. Cell Biol. 14: 684-691.

Storchova, Z. and Pellman, D. 2004. From polyploidy to aneuploidy, genome instability and cancer. Nat. Rev. Mol. Cell Biol. 5: 45-54.

Taylor, M.D., Gokgoz, N., Andrulis, I.L., Mainprize, T.G., Drake, J.M., and Rutka, J.T. 2000. Familial posterior fossa brain tumors of infancy secondary to germline mutation of the hSNF5 gene. Am. J. Hum. Genet. 66: 1403-1406.

Versteege, I., Sevenet, N., Lange, J., Rousseau-Merck, M.F., Ambros, P., Handgretinger, R., Aurias, A., and Delattre, O. 1998. Truncating mutations of hSNF5/INI1 in aggressive paediatric cancer. Nature 394: 203-206.

Versteege, I., Medjkane, S., Rouillard, D., and Delattre, O. 2002. A key role of the hSNF5/INI1 tumour suppressor in the control of the G1-S transition of the cell cycle. Oncogene 21: 6403-6412.

Wiegant, J., Bezrookove, V., Rosenberg, C., Tanke, H.J., Raap, A.K., Zhang, H., Bittner, M., Trent, J.M., and Meltzer, P. 2000. Differentially painting human chromosome arms with combined binary ratio-labeling fluorescence in situ hybridization. Genome Res. 10: 861865.

Zhang, Z.K., Davies, K.P., Allen, J., Zhu, L., Pestell, R.G., Zagzag, D., and Kalpana, G.V. 2002. Cell cycle arrest and repression of cyclin D1 transcription by INI1/hSNF5. Mol. Cell Biol. 22: 5975-5988. 


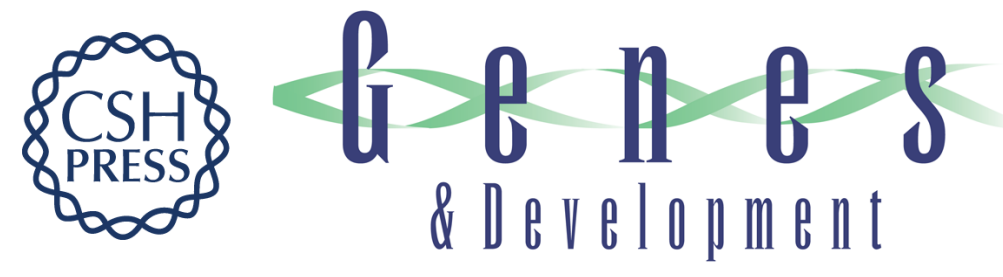

\section{Cancer-associated mutations in chromatin remodeler hSNF5 promote chromosomal instability by compromising the mitotic checkpoint}

Robert G.J. Vries, Vladimir Bezrookove, Lobke M.P. Zuijderduijn, et al.

Genes Dev. 2005, 19:

Access the most recent version at doi:10.1101/gad.335805

References This article cites 34 articles, 10 of which can be accessed free at: http://genesdev.cshlp.org/content/19/6/665.full.html\#ref-list-1

License

Email Alerting

Receive free email alerts when new articles cite this article - sign up in the box at the top Service right corner of the article or click here.

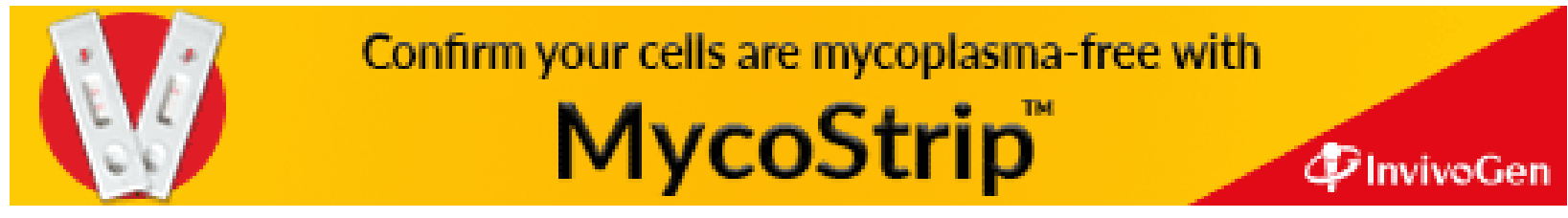

